\title{
New therapeutic approaches in the treatment of low back pain
}

\author{
Marius NECULĂEȘ ${ }^{1}$, Paul LUCACI ${ }^{2}$
}

\begin{abstract}
Medical recovery practices have welcomed more and more patients complaining about moderate or intense low back pain. Aim: This paper aims to demonstrate the efficiency of successive magnetic induction therapy on low back pain syndrome. We assume that the use of successive magnetic induction in the treatment of patients with low back pain will reduce significantly the pain manifestations at this level.

Methods: The study was conducted on 30 patients who displayed important low back pain and decreased lumbar spine mobility. The therapy applied - super inductive system - reduced significantly the pain threshold of these patients and improved the lumbar spine mobility, implicitly.

Results: In order to highlight the results, we interpreted graphically the values of the initial and final testing using the Microsoft Office Excel. There is no doubt that the mobility of the lumbar spine of patients improved considerably, some patients reported that their pain disappeared altogether, while others reported only a mild discomfort.

Conclusion: This study stands to highlight the efficiency of the Super Inductive System, a fact confirmed by the comparison between initial and final results.

Keywords: herniated disc, successive magnetic induction, therapy.
\end{abstract}

\section{Rezumat}

La cabinetele de recuperare medicală se prezintă un număr din ce în ce mai mare de persoane care acuză dureri lombare de intensitate medie sau mare.

Scop : Lucrarea de față își propune să demonstreze eficiența terapiei prin inducție magnetică succesivă asupra sindromului dureros lombar. Presupunem că folosirea inducției magnetice succesive în tratarea pacienților cu dureri lombare va reduce semnificativ manifestările dureroase de la acest nivel.

Metode : Studiul s-a realizat pe 30 de pacienți ce au prezentat dureri importante la nivel lombar și o diminuare semnificativă a gradului de mobilitate la nivelul coloanei vertebrale lombare. Terapia aplicată, Super Inductive System, a redus semnificativ pragul de durere al acestor pacienți și implicit a condus la îmbunătățirea mobilității coloanei lombare.

Resultate : Pentru interpretarea rezultatelor am realizat reprezentarea grafică a valorilor obținute la testarea inițială și finală utilizând programul Microsoft Office Excel. Fără îndoială mobilitatea coloanei vertebrale lombare a pacienților s-a îmbunătățit considerabil, unii pacienți afirmând că durerea a dispărut în totalitate, în timp ce alții au afirmat că mai simt doar un mic discomfort.

Concluzie : Studiul evidențiază eficiența terapiei cu Super Inductive System, fapt confirmat prin compararea rezultatelor inițiale cu cele finale.

Cuvinte cheie: hernie de disc, inducție magnetică succesivă, terapie.

\footnotetext{
${ }^{1}$ Lecturer PhD, “Alexandru Ioan Cuza” University, Iași, Faculty of Physical Education and Sport, Romania, email: neculaes_marius@yahoo.com

${ }^{2}$ Teaching Assistant, "Alexandru Ioan Cuza" University, Iași, Faculty of Physical Education and Sport, Romania
} 


\section{Introduction}

Low back pain is a very common issue among the general population; each person had at least once in their life a back pain that interfered with their professional or their daily activities. Fortunately, most cases of low back pain can be solved within a matter of days. Other cases require a longer period to solve, and the lack of proper treatment may lead to serious issues by aggravating symptomatology. Low back pain proved to be one of the major health issues in urban societies; a percentage ranging between $58 \%$ and $70 \%$ of the population experienced lumbar spine pain in a certain point in their lives [1].

Back pain, for instance, may emerge when a person lifts too heavy of a weight, which causes a strain, a tear or a spasm in the muscles or ligaments of the back. If the pressure on the spine is excessive, a tear or prolapsed (bulged) intervertebral disc may occur. Such prolapsed disc puts pressure on one of the spinal nerve roots. When the nerve root is compressed or irritated, back pain emerges. In addition, low back pain may appear as a consequence of maintaining a faulty posture for a long time, extended standing and repeated mechanical stress on the lumbar spine, thus leading to muscular contracture that generates pain and discomfort.

Back pain is defined as persistent or chronic when it exceeds 3 months or 12 weeks Symptoms are diverse and they include: alteration of physical functions such as limited mobility, memory disorders (irritability), dysfunctions (decreased capacity of concentration) and mental symptoms (anxiety and depression)[2].

Many of the professions involve repeated and prolonged movements of raising up, standing, twisting, all of them being associated with an increase in musculoskeletal disorders, especially with lumbar spine pain, leading to functional acute negative and possibly long-term effects. This risk led to the use of mechanical elevators and of other mechanical devices that help workers [3]. In order to prevent the emergence of spinal pain, a great deal of importance has been given to the school of the

\section{Material and methods}

spine, which consists in a series of rules to respect, regarding the position of the lumbar spine during various activities. The relation between back posture and low back pain has not been entirely understood, but strong correlations have been found between low back pain and its rotated and flexed position. Compared to the position of orthostatism, the sitting position mitigates lumbar lordosis ant it increases the activity of low back muscles, the disc pressure and the ischial pressure, which associates with the emergence of low back pain [4]. This setback may be compensated by using a support for the vertebral spine, attached to the working chair.

Non-specific low back pain constitutes a social but also economic issue; a correct therapeutic approach is important for both the patient and the society [5]. This pain represents a disorder that affects the muscles and bones of the back and it is characterized by moderate to severe lower back pain. It is different from occasional back pain caused by activities the vertebral spine or by those in which the individual maintains a faulty posture for a long time, the causes of which are often unknown.

It is assumed that the lack of physical activity is associated with high risk of relapse concerning low back pain, but other contradictory data refer to an association between pain and intense effort such as in fitness [6]. This is why it is necessary to observe the methodological principles of physical exercise: from easy to hard and from simple to complex.

The importance of approaching the issue of low back pain is greater as the emergence of this type of pain is recorded at younger and younger ages. Several studies highlight that the faulty postures adopted by students during classes and at home represent one of the factors leading to the development of back pain [7].

The risk factors in the emergence of lumbar spine pain are the following: obesity, lack of physical activity, hereditary factors, faulty postures, smoking, alcohol, protein deficiencies, low living standards and pregnancy [8].

The study was conducted on a sample of 30 patients with low back pain, aged between 25 and 40, among whom 20 were male and 10 were female. From 
them, 20 patients suffered from acute lumbar discopathy (13 males and 7 females), 3 from algetic paresthesic lumbosciatica (males) and 7 from acute lower back pain ( 5 males and 2 females). Initial and final assessments included the Schober test and the Visual Analogue Scale.

Patients were submitted to electromagnetic waves induced successively by the BTL 600 device, also called the Super Inductive System. This innovative therapy influences rapidly the human body tissues, thus facilitating considerable pain mitigation, accelerated healing of fractures, muscle relaxation and stimulation, increasing joint range of motion. This device may be used for treating both acute and chronic pain, thus influencing positively both the musculoskeletal complex and the nervous system. By using the specific settings, the device may lead to the desired muscular outcomes (relaxation, toning), thanks to the interaction between the electromagnetic field and the tissue. Due to repetitive contractions of periarticular muscles, an improvement of joint mobility can be obtained. The Super Inductive System acts through a bobbin located in the applicator that enters directly in contact with the human body, namely the affected area, thus producing the depolarization of the neuromuscular tissue.

The treatment position of patients with acute lower back pain and algetic paresthesic lumbosciatica consisted in sitting on a chair, the head leaning against the forearms, in their turn placed on an adjustable treatment table; the position of patients with acute lumbar discopathy was ventral decubitus on the treatment table, with a roll under the abdomen.

The patients with acute lower back pain had 4 days of treatment, with 2 applications with different programs on the painful area (Vertebral Syndrome and Miorelaxation) for 20 minutes. Patients suffering from algetic paresthesic lumbosciatica benefited from 5 days of treatment, also comprising 2 applications per day with different programs (Syndrome Lumbosacralis and Split Disc) for 20 minutes. Patients with acute lumbar discopathy benefited from 3 days of treatment, consisting in 2 applications with different programs (Vertebral Syndrome and Analgesia Acuta) for 20 minutes.
In order to highlight the results, we interpreted graphically the values of the initial and final testing using the Microsoft Office Excel. Hence, we drafted up graphs to illustrate the results obtained at the beginning of the study compared to those obtained after applying the Super Inductive System therapy.

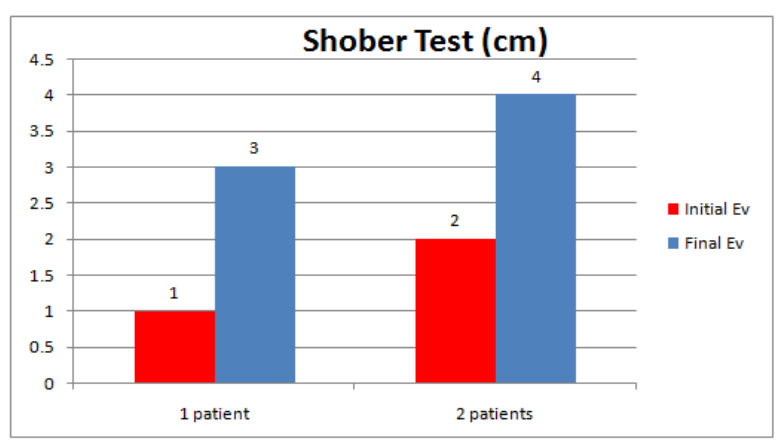

Figure1. Evaluation of spine mobility in patients with algetic paresthesic lumbosciatica

According to Figure 1, the lumbar spine mobility increased by $2 \mathrm{~cm}$ on average, after applying the Super Inductive System therapy. Patients managed to resume their usual movements without feeling stiffness at the lumbar spine, which limited both the range of motion and the speed of execution.

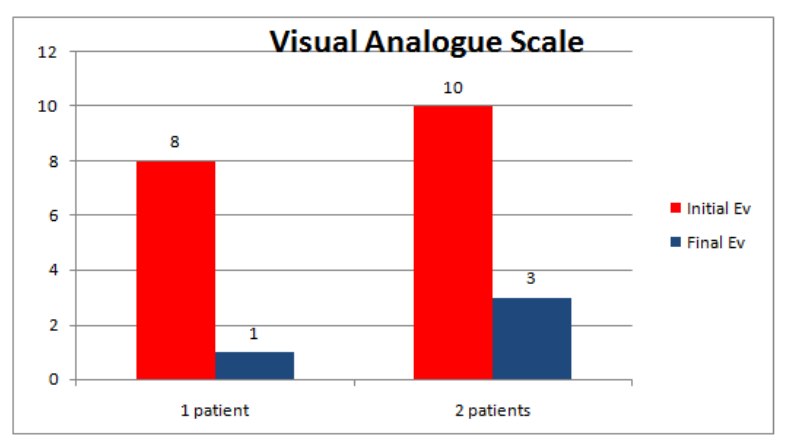

Figure 2. Pain evaluation in pacients with algetic paresthesic lumbosciatica

Figure 2 shows that the pain intensity of the patients with algetic lumbosciatica was mitigated by 7 points on average on the Visual Analogue Scale.

Whereas at the beginning the pain was unbearable and barely tolerable, after applying the Super Inductive System, it decreases to the sensation of mild to no pain.

\section{Results}




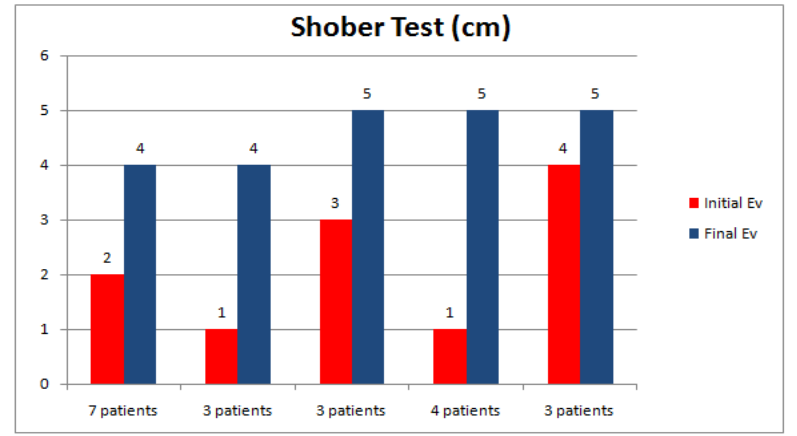

Figure 3. Evaluation of spine mobility in patients with acute lumbar discopathy

The spine mobility of patients with acute lumbar discopathy improved considerably; it even reached normal values for most of the patients.

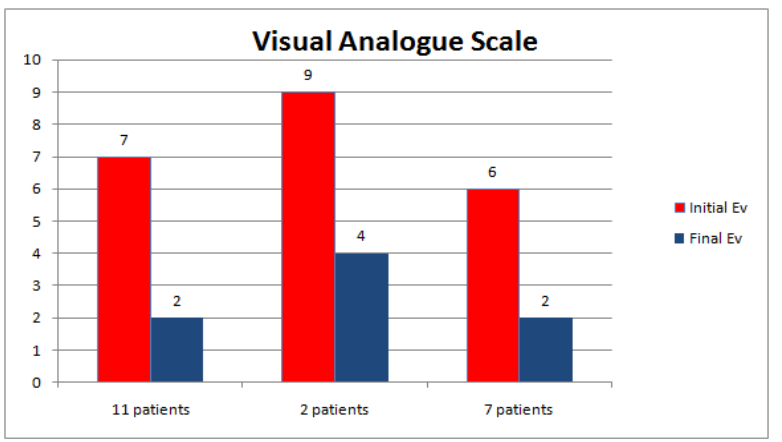

Figure 4. Pain evaluation in pacients with acute lumbar discopathy

Figure 4 underscores that the 20 patients suffering from acute lumbar discopathy recorded a significant decrease in pain intensity, with an average of 6.44 points on the Visual Analogue Scale, after this therapy.

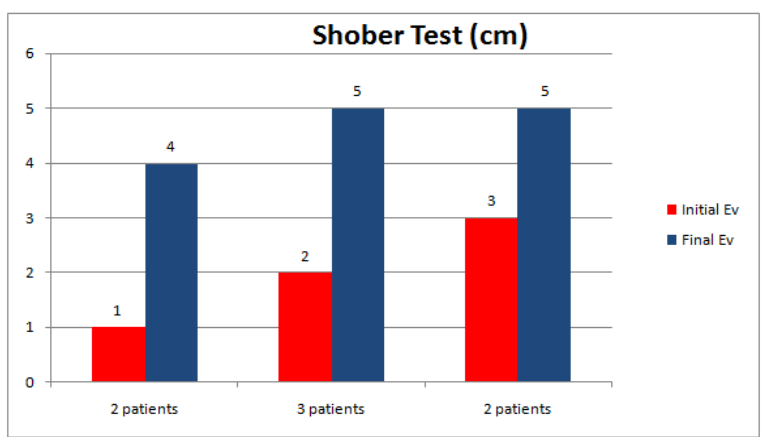

Figure 5. Evaluation of spine mobility in patients with acute low back pain.

Figure 5 shows that, in patients with acute low back pain, also, the spine range of motion improved considerably after applying this therapy, with an average of $2.66 \mathrm{~cm}$.

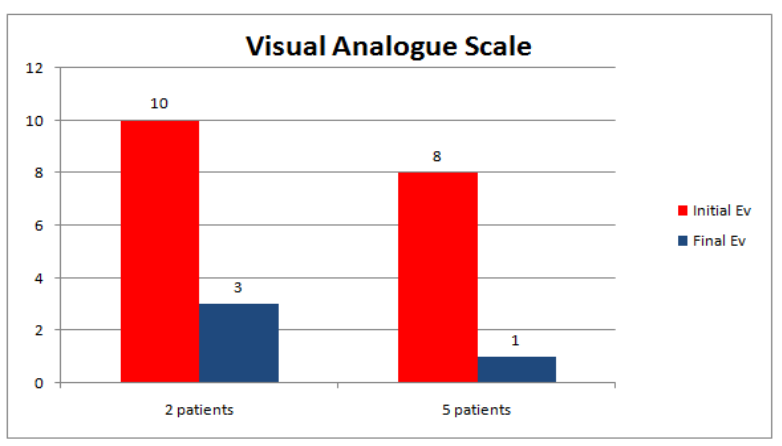

Figure 6. Pain evaluation in patients with acute low back pain

As shown in Figure 6, pain intensity mitigated significantly; patients stated that the symptoms experienced before the therapy became almost imperceptible. The improvement average is of 7 points on the Visual Analogue Scale.

\section{Discussion}

Other studies show the benefits of electrotherapy in the treatment of low back pain.

The low level laser treatment accelerates the overall healing process through interaction with the targeted tissues while using precise wavelengths of light [1].

The use of electromagnetic fields in health has a long past history, and the healing effects represent a useful treatment of the painful conditions of the neuromuscular and joint-skeletal system.

\section{Conclusions}

This study stands to highlight the efficiency of the Super Inductive System, a fact confirmed by the comparison between initial and final results.

There is no doubt that the mobility of the lumbar spine of patients improved considerably; in most cases, it reached normal values.

Furthermore, concerning the mitigation of pain intensity, some patients reported that their pain disappeared altogether, while others reported only a mild discomfort.

The efficiency of BTL-6000, which uses the magnetic super inductive system, is all the more obvious as some patients reported significant symptom mitigations in a very short time. 
The Super Inductive System is a rapid therapy, given that it only takes 20 minutes per day.

Our confidence in the effects of the therapy was also increased by the fact that, during the treatment, patients did not take any medication or benefit from another treatment (kinesiotherapeutic or of another nature); electromagnetic induction applications were the only therapy they had throughout the duration of the research.

\section{References}

1. Tarek F., Osama F.A., Mohamed S., Ragia M.K. (2017). Effect of Low Level Laser versus McKenzie Technique in Treatment of Chronic Low Back Pain, J. Bioengineer \& Biomedical Sci., 7: 228.

2. Rofail D., Myers L., Froggatt D. (2016). Treatment Satisfaction and Dissatisfaction in Chronic Low Back Pain: a Systematic Review, J. Psychol. Psychother., 6: 260.
3. Rishiraj N. (2015). A Brief Review of Physical and Psychosocial Factors Involved in Chronic Low Back Pain, Occup. Med. Health. Aff., 3: 201.

4. Karunanayake Aranjan Lionel (2014). Risk factors for chronic low back pain in adults. A case control study done in Sri Lanka, J. Pain Relief., 3: 162.

5. Paolucci T., Zangrando F., Allemanini V., Vulpiani M.C., Saraceni M. (2013). Low Back Pain Rehabilitation Using Motor Imagery. Gen. Med. (Los Angel)., 1: 119.

6. Atikovic A., Tabakovic M., Kostovski Z., Zahirovic J., Kalinski S.D., et al. (2017). Low Back Pain of Faculty of Sport and Physical Education Students in Relation to Different Activities, J. Pain Relief., 6: 290.

7. Minghelli B. (2017). Low Back Pain in Childhood and Adolescent Phase: Consequences, Prevalence and Risk Factors - A Revision, J. Spine, 6: 1000351.

8. Lionel K.A. (2014). Risk Factors For chronic Low Back Pain, J. Community Med. Health. Educ., 4:271. 